\title{
How The Storyteller Became Medallion Man
}

\section{Michael Morpurgo \\ Children's Laureate}

Let me go on as I mean to go on, with a story, with two stories really - one is mine and one is not. Here's mine:

There was once a small boy who loved being read to at night as he chewed on his quartered apple and watched his mother's mouth. His mother used to read poetry to him Kipling, de la Mare, Tennyson, Masefield.

'I must go down to the sea again, to the lonely sea and the sky.'

'Is there anybody there said the Traveller.'

'He crasps the crag with crooked clans.'

She read stories, Kipling's Just So Stories: The Elephant's Child, The Cat that walked by Itself. The words were like music to him. He simply loved the sound of them, his mother speaking them. But when the boy first went to school he began to hate poems, to fear them even, because he had to learn them and then to stand up and recite them out loud in front of everyone. The music in the words died.

In the years that followed he read only Stevenson whom he adored and Blyton who he consumed like Rowntree's Fruit Gums. Later in school, in university he learnt that poems and novels were for analysing and criticising, but the words and stories themselves were all withered things by now.

Then one day he read Sir Gawain and the Green Knight. And was entranced again. The story was wonderful to him and the words sang again as they had before. In time he became a husband and a father and a teacher, and witnessed from a different perspective the power of poetry and story, the sheer intensity of private pleasure his own children and the children he taught seemed to be able to enjoy.

At school he read to his children stories, poems, but only poems and stories he loved. He encouraged the children in his class to write, to tell what they saw and heard and felt. He tried to inspire them and in so doing he accidentally inspired himself. He read 'Poetry in the Making ' by a great poet Ted Hughes - there never was a more persuasive invitation to write and began slowly to believe that he might be able to tell his stories himself. His wife encouraged him to tell his stories out loud to his class. The children stopped looking out of the window, stopped picking their noses. He could do it! He had become a storyteller.

With each story he was growing in confidence, feeling his way, finding his voice. He wrote his stories down, and one day a nice editor at Macmillan Education called Aidan Chambers published his first book. 
Writing and teaching seemed to go well together, like bread and jam, but the storyteller and his wife decided to exchange the classroom for a farm, his wife's idea, and good one too.

So moving to Devon the storyteller became a farmer/teacher/writer. Each day now he and his wife would work with children out on the farm. They came from big cities and towns in groups of 40 with their teachers to find out about the countryside, to learn where their food came from, why Wordsworth wrote 'Daffodils', to see stars, to listen to the aark of a heron and see a pair of buzzards mewing over the trees, to see larks rise and disappear.

The storyteller introduced them to this new world, listened to them, watehed them and read his stories to them.

Then one summer evening late, while strolling in the water meadows, a great poet came darkly up out of the river. So the storyteller met the great poet (who had written Poetry in the Making) and then they became friends, then good friends, then great friends. The great poet read the storyteller's latest book War Horse and like God (it seemed to the storyteller) at the time of the creation 'saw that it was good' and said so. Thus encouraged the storyteller wrote more and dared more with each book.

Then one evening by the fire after a feast of salmon the storyteller asked the great poet (who by now was the Poet Laureate) whether he considered his stories and poems for children to be lesser in any way than his stories and poems for adults (grown-up children). Not at all, he said.

So why, in that case, asked the storyteller, who wrote books mostly read by children, why is it that children's literature, however good, is generally considered to be inferior, of less significance than adult literature? The great poet paused and said, "A good book, a well written book, is significant, whoever it's for."

The storyteller looked into the flames and had a sudden, exciting idea, the kind he often had when a new story comes into his head. He spoke his idea. "What if there were to be a children's laureate appointed, he said, not regal like you, but someone who would enthuse children and adults alike, about children`s stories and poems and illustration and drama might that make a difference as to how the world perceives children's literature?" "A terrific idea," said the great poet, which pleased the storyteller. "So why don't we do it," the great poet went on - which was not at all what the storyteller had in mind. It had just been an idea to him. "We'll find a sponsor. I'll write to Tim Waterstone," said the great poet. "We'll get the government behind us. I'll write to Chris Smith. And I know just the person who could bring the whole thing to life and make it happen - Lois Beeson. You know her," he said "You ask her."

So the storyteller asked Lois Beeson who had done such great work with the Poetry Society and the WH Smith Children's Literary Competition and The Young Writer Magazine.

Lois got a steering group of wise people together, talked to publishers, writers and illustrators, and LISTENED. She knocked the whole thing into shape, found the money, gave it integrity and purpose, made it possible and relevant. Within 2 months the first Children's Laureate was appointed, the wonderful Quentin Blake. But sadly, sadly by this time the great poet had become ill and died. From a distance the storyteller looked on as almost single- 
handedly now, and certainly single-mindedly, Lois carried on. She helped and shepherded Quentin through his time as Laureate. Then two years on came the second Children's Laureate, the inspirational Anne Fine. Still fundraising, still driving the project on, Lois helped Anne through her first year. But then Lois herself fell ill and died before the 3rd Children's Laureate was appointed. The storyteller felt bereft as were all her family and friends because she was such a rare person, a loving and loyal friend, who gave herself unstintingly to the Children's Laureate in the last years of her short life. So when the storyteller received a call asking him if he would be the 3rd Children's Laureate he felt overwhelmed, by grief and doubt and excitement but he felt the time was right.

So that is how the young boy who was a reluctant reader became a storyteller and has now become medallion man.

And what will the storyteller do now that he's Children's Laureate?

Well he will go on telling his tales.

The best stories have endings that are not endings. The Children's Laureate is an ever changing, never ending story. For the next two years the storyteller gets to write the next chapter. He will hope to follow in the footsteps of his extraordinary predecessors - QB or Kontan Black as he is known in France - who by being himself brought us all - adults and children alike - to a greater understanding and appreciation of illustration and continues to do so with his projected gallery of illustrators in London which we must all support in every way we ean. And Anne Fine who made us sit up and think. No one could have been more committed. Her Home Libraries project is innovative and hugely successful. She stood up for what she believes in - libraries that stay open and books that are worthy of children. Both have been the most wonderful champions of and for children's literature.

As for the storyteller, he wants first of all in memory of Lois Beeson to put on a reading of poetry for children by some of our great poets. It will take place this Oetober at the South Bank. He'd like you all to be there if you can be, to remember her. And he wants at once to begin to work out with Lindsay Frazer and the Book Trust how best he can use his two years. Between them, Lindsay and The Book Trust will be administering the Children's Laureate from now on. He knows that Lindsay is just the right person to pick up the baton for she has worked all her life to promote all that is best in Children's Literature. She will bring it her quiet sureness of touch, her drive. With her and The Book Trust, with his friends writers, illustrators, poets, dramatists, editors, booksellers - all from this vibrant and exciting world of children's books where there is a great kindred spirit, he will seek to enthuse, to bring more children to reading and writing. Quentin and Anne had the right idea. The best way is to be yourself, do what you do best.

So I shall tell my stories wherever I go, far and wide, to teachers, to parents, to children, to anyone who is interested, to show that literature comes before literacy - and let's call it the literature hour instead - for we want more children, all children (grown up ones too!) to discover and rediscover the secret pleasure that is reading, and help them to find their voice in their own writing. 
It's how the storyteller started out, if you remember, when he was a young teacher. So to finish here's a wonderful and short story by a young writer, Simon Abbey aged 8 . I included it in my first little book Children's Words in '97'. Here it is:

\title{
GAME OF DENTISTS
}

The night before I went to the dentists, my sister and I were playing at dentists. She stamped on the floor that made the chair go up. She then switched on a lite. She used a pair of pliars out of my tool set for the pinchers. She used my bobble hat for the gas mask. She used a puddin dish for the thing that you spit your blud into. She used a poker for the drill and a glass of water for the mouth wash. She tied me to the chair with some thick string and tied a hanky round my neck. She got a lolly stick and prest my tong back to see which tooth to pull out. She put a bit of rock in my mouth to keep it open and put my bobble hat on me. She took it off and got the pair of pliars and pretended to pull out my tooth. She took a look at it and then gave me the water and I pretended to wash out my mouth. She untied the hanky, but she didn't untie me from the chair. She hit me about ten times and then ran off. I shouted mum to come and untic me. After that next time we play shes defenetly going to be the patient.

\section{Author Note}

\begin{abstract}
Having taught for ten years in both state and private schools, Michael still works frequently in schools as visiting author. His first book was published in 1975 and he has since published over ninety titles. His books have been translated into over twenty languages. In 1976 Michael and Clare Morpurgo founded Farms for City Children, an educational charity which now runs three farms welcoming over 3000 children a year. Michael was awarded the MBE in 1999 for services to youth. In 2003 he became Children's Laureate, a two-year honour during which he wants to focus on the power of story and the sheer enjoyment of literature, and to talk about this to as many children and teachers as possible. Michael is an Hon Doctor of Education at the University of Plymouth, a Fellow of Kings College, London, winner of the Whitbread Children's Book Award, Smarties Prize, Federation of Children's Book Award, Writer's Guild Award, Cercle D'Or, Prix Sorciere (France), and Silver Pencil (Holland).
\end{abstract}

